\title{
Artykuey
}

KLIO. Czasopismo poświęcone dziejom Polski i powszechnym

PL ISSN 1643-8191, t. 23 (4)/2012, s. 129-142

\section{Jerzy Dygdaa \\ (Toruń) \\ Listy Rady Torunia w XVIII wieku: adresaci, częstotliwość, zasięg terytorialny}

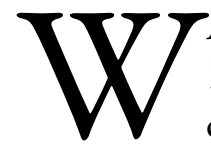

Archiwum Państwowym w Toruniu jest przechowywana seria 17 ksiąg (Missiva, Briefbücher), do których wpisywano kopie wychodzącej oficjalnej korespondencji Rady miasta z lat 1703-1792. Wcześniejsze księgi uległy zniszczeniu w pożarze ratusza, gdzie przechowywano archiwum miejskie, podczas oblężenia Torunia przez Szwedów w 1703 r. Nieliczne zachowane kopie wcześniejszych pism (z lat 1570-1694) wpisano później do odrębnej księgi o sygnaturze Katalog II, I 44. Podstawą sporządzania tych kopiariuszy były, jak można przypuszczać, redagowane przez sekretarzy miejskich koncepty (bruliony) pism przygotowywanych do wysłania. Księgi te szczegółowo scharakteryzowała pod względem kancelaryjnym i archiwalnym długoletnia dyrektor archiwum toruńskiego doc. dr Karola Ciesielska ${ }^{1}$, ale nie analizowała bliżej ich zawartości. Tymczasem kopiariusze te mogą być podstawą do określenia liczebności, częstotliwości i zasięgu korespondencji Rady Torunia.

Poniższe studium ma charakter sondażowy. Wziąłem pod uwagę listy toruńskiej Rady z co piątego roku, poczynając od 1705 do 1790 r. Dodatkowo przeanalizowałem korespondencję z kilku specyficznych lat, w czasie których

${ }^{1}$ K. Ciesielska, Missiva w kancelarii miasta Torunia w XVIII wieku, [w:] Historia i archiwistyka. Ksiega pamiątkowa ku czci Profesora Andrzeja Tomczaka, red. J. Dygdała, B. Woszczyński, Toruń-Warszawa 1992, s. 177-187. 
zachodziły ważne dla miasta wydarzenia. W roku 1724 doszło do tzw. tumultu toruńskiego zakończonego ścięciem mieszczan oskarżonych o dewastację kolegium jezuickiego lub o niezaprowadzenie porządku oraz zmianami w składzie władz miejskich. Rok 1733 to czas bezkrólewia i wzmożonej aktywności polityków miejskich, a 1767 wiąże się z powstałą w Toruniu konfederacją dysydencką i zabiegami o przyznanie różnowiercom pełni praw politycznych. Chciałem poddać analizie także materiały z 1772 r., kiedy to w wyniku I rozbioru Toruń został odcięty zarówno od ziem polskich jak i od Gdańska, ale księga z kopiami listów z lat 1771-1774 zaginęła i to jeszcze w końcu XVIII w. ${ }^{2}$

W badanych okresach najwięcej oficjalnych listów Rada Torunia wysłała w 1710 r. (185), 1767 r. (174) i w 1765 r. (173). Były to lata wojny północnej, kiedy to miasto korespondowało przede wszystkim z oficerami wojsk rosyjskich, saskich, koronnych i litewskich żądających od miasta kwater i dostaw, następnie aktywnej działalności polityków toruńskich w konfederacji dysydenckiej z 1767 r., wreszcie zabiegów o nieobejmowanie miasta reformami (m.in. menniczymi) podejmowanymi w początkach panowania Stanisława Augusta. Najmniej listów Rady wyszło z Torunia w 1790 r. (87), 1745 r. (89) i 1785 r. (92). Wyraźne zmniejszenie się częstotliwości korespondencji u schyłku XVIII w. wynika z ograniczenia kontaktów z władzami centralnymi Rzeczypospolitej, ale też i z dwoma głównymi ośrodkami miejskimi w byłych Prusach Królewskich, to jest z Gdańskiem i Elblągiem. Liczebności listów odpowiadała tė̇ ich łączna objętość. W 1710 r. obejmowała ona aż 292 s. kopiariusza, w 1767 r. - 252 s., w 1715 - 235 s. i w 1765 r. - 222 s. Najmniej miejsca zajęły kopie listów z 1745 r. (74 s.), z 1705 r. (82 s.), z 1755 r. (83 s.) i z 1790 r. (88 s.). W latach 1705-1790 przeciętnie wysyłano z Torunia około 130 oficjalnych listów Rady rocznie. Objętość tych listów w skali roku wynosiła około 170 stron.

Warto zwrócić uwagę na fakt, że po 1724 r., kiedy to w skład Rady weszli również katolicy (żaden z nich nie był jednak uprzednio sekretarzem ani kancelistą w kancelarii miejskiej), nie wszystkie pisma Rady były wpisywane do sporządzanych na ogół na bieżąco kopiariuszy wysyłanej korespondencji. Kopie pism dotyczących spraw wyznaniowych (m.in. zamierzonej budowy nowego kościoła protestanckiego, czy kwestii równouprawnienia dysydentów) znalazły się w odrębnej księdze (sygnatura Kat. II, I 42) o objętości 313 s. obejmującej kilkadziesiąt listów wysłanych między 17 XI 1738 a 27 VIII 1766 r. ${ }^{3}$

2 Ibidem, s. 179.

3 Ibidem, s. 179. 
Analizując liczebność listów wysyłanych do poszczególnych grup adresatów, możemy stwierdzić istnienie silnej pozytywnej zależności (korelacji) z ważnymi wydarzeniami politycznymi. W 1705 r., w czasie wojny północnej, aż 37\% korespondencji skierowane było do oficerów i ministrów obcych państw (szwedzkich, rosyjskich, saskich). Podobna proporcja wystąpiła w 1760 r. (34\%), kiedy to walczące przeciw Prusakom wojska rosyjskie przez dłuższy czas stacjonowały w Toruniu, mniej tego typu listów (14\%) wysyłano natomiast w 1775 r. do dowódców oddziałów pruskich, stojących wokół miasta.

Toruń, Elbląg i Gdańsk, jako tzw. wielkie miasta Prus Królewskich, miały miejsce w wyższej izbie (senacie) samorządu sejmikowego prowincji ${ }^{4}$. Odgrywały też istotną rolę w życiu politycznym i gospodarczym Prus Królewskich. Z tego też powodu miasta te utrzymywały stałe kontakty, uzgadniały swoje postępowanie i niejednokrotnie razem występowały na arenie politycznej, chociażby wysyłając wspólne listy do władców i centralnych urzędów Rzeczypospolitej. Sytuacja ta dobrze odzwierciedlona jest także w kopiariuszach korespondencji toruńskiej Rady. Zwłaszcza w latach kiedy odbywały się sejmy i poprzedzające je sejmiki generalne Prus Królewskich zwiększa się liczba listów kierowanych jednocześnie do obu siostrzanych miast. W 1710 r. Rada Torunia wysłała 16 takich listów, w 1724 r. - 10, w 1730 r. - 18, w 1733 r. 17. Później liczba ta znacząco się zmniejsza (sejmiki w Prusach Królewskich nie dochodzą do skutku). Dopiero w latach 1765 i 1767 (spory o cło generalne, nową monetę, kwestia dysydencka) z Torunia wychodzi po 35 i 47 (27\% całorocznej korespondencji) listów do Gdańska i Elbląga. Po 1772 r., kiedy to Elbląg znalazł się pod panowaniem pruskim, tego typu pisma przestały być wysyłane, Rada Torunia konsultowała swoje posunięcia jedynie z Radą Gdańska.

Kolejne miejsce pod względem liczebności zajmują listy kierowane do toruńskich sekretarzy-rezydentów przebywających na dworze polskim (i polsko-saskim w Dreźnie) oraz do deputowanych Torunia wysyłanych na sejmiki generalne, sejmy, czy załatwiających różne sprawy miejskie w stolicy. W latach 1710 i 1715 pisma te stanowią nawet 31\% i 34\% całej miejskiej korespondencji. Później odsetek tych listów nieco się zmniejsza, ale jeszcze w 1735 r. wynosi on $29 \%$. W kolejnych latach te oficjalne pisma Rady stają się jednak coraz rzadsze. Jedynie w 1765 i 1767 r. pojawiają się one znowu w nieco większej liczbie

${ }^{4}$ Z. Naworski, Sejmik generalny Prus Królewskich 1569-1772. Organizacja i funkcjonowanie na tle zgromadzeń stanowych prowincji, Toruń 1992, s. 97-98, 105-114; S. Achremczyk, Życie sejmikowe Prus Królewskich w latach 1647-1772, Olsztyn 1999, s. 94-98. 
sięgając zaledwie 9\%. Nie oznacza to jednak, że miasto nie utrzymywało ożywionych kontaktów ze swymi przedstawicielami na dworze. Zwłaszcza podczas długoletniej misji sekretarza (potem rajcy) Samuela Lutra Gereta w Warszawie w latach 1761-1776 praktycznie każdą pocztą (co tydzień), a także przez specjalnych posłańców, wysyłano do niego listy z instrukcjami i poleceniami, z tym że na ogół nie były to formalne pisma Rady, a tylko listy zaufanych sekretarzy i kierującego ówczesną polityką miejską burmistrza Chrystiana Klosmanna. Ponadto w razie konieczności nieoficjalne (ale za to obszerne) instrukcje przesyłała Geretowi tzw. Rada Ewangelicka złożona wyłącznie z rajców protestanckich. Tak więc co roku wychodziło wówczas z Torunia do stolicy po kilkadziesiąt (niekiedy ponad sto) poufnych listów skierowanych do toruńskiego rezydenta. Nie były one oczywiście wpisywane do oficjalnych kopiariuszy, do których mieli dostęp także katoliccy członkowie Rady. Wydaje się, że w latach czterdziestych XVIII w. uznano za bezpieczniejsze porozumiewanie się z rezydentami na dworze przez zaufanych sekretarzy, a oficjalne listy Rady wysyłano tylko w razie konieczności, przy czym po 1775 r. praktycznie w ogóle one się już nie pojawiają w kopiariuszach 5 .

Rada Torunia musiała oczywiście utrzymywać stałe kontakty pisemne z centralnymi władzami Rzeczypospolitej. Praktycznie przez cały badany okres pojawiają się listy skierowane do monarchów polskich. Liczba tych pism waha się od 1 do $7 \mathrm{w}$ skali roku, jedynie w 1724 r. sięga 11. Obawiając się skutków tzw. tumultu toruńskiego, Rada wielokrotnie zwracała się do Augusta II, wyjaśniając całą sprawę i prosząc (bezskutecznie) o łaskawość względem miejscowych ewangelików. Najczęściej władze Torunia kontaktowały się z kanclerzami, w gestii których spoczywał nadzór nad miastami. Co roku wysyłano do nich po kilka, kilkanaście listów prosząc o interwencje na rzecz miasta w sądach asesorskich i trybunalskich, pomoc w razie konfliktów z kupcami z obcych państw, odpierając zarzuty o dyskryminację katolików w mieście, czy szukając poparcia w obliczu zagrożenia pruskiego po 1772 r. Niekiedy kanclerze (np. Jan Szembek) bezpośrednio interweniowali w spory wewnętrzne w mieście ${ }^{6}$. Pojedyncze listy wysyłano także do marszałków koronnych - najwięcej (10) przesłano w 1760 r. do marszałka nadwornego koronnego Jerze-

5 Por. szerzej J. Dygdała, Korespondencja rezydentów miasta Torunia na dworze królewskim w XVIII wieku w Archiwum Toruńskim, „Acta Universitatis Nicolai Copernici. Historia” 1973, t. 8, s. 89-90, 96-99.

${ }^{6}$ Idem, Konflikty spoteczno-ustrojowe w Toruniu w latach 1716-1718 (Mediacja kanclerza wielkiego koronnego Jana Szembeka), „Zapiski Historyczne” 1983, t. 48, z. 3, s. 71-103. 
go Augusta Mniszcha, stojącego wówczas na czele nieformalnego stronnictwa dworskiego. Podskarbiowie koronni byli znacznie rzadziej adresatami listów toruńskiej Rady, co może budzić zdziwienie, gdyż to w ich ręku były sprawy podatkowe i skarbowe. Należy jednak pamiętać, że od 1717 r. podatki były stałe, a zniżkę opłat celnych dla kupców toruńskich załatwiono pomyślnie z podskarbim Janem Jerzym Przebendowskim w latach 1720-1722 $2^{7}$. Kontaktowano się więc z nimi tylko w razie pojawienia się sporów z lokalnymi urzędnikami celnymi. Do hetmanów koronnych wysłano tylko kilka listów w dobie wojny północnej i aż 7 pism w 1724 r., kiedy to wojsko, po tzw. tumulcie toruńskim, miało zabezpieczyć egzekucję surowego wyroku sądu asesorskiego.

Stosunkowo dużo listów przesyłała Rada do senatorów Prus Królewskich. Wynikało to z zasiadania miasta w senacie pruskim i uzgadniania wielu bieżących spraw prowincji, ale też były tam prośby o interwencje na rzecz Torunia na dworze królewskim, czy w sądach trybunalskich. Wyodrębniłem tu biskupów warmińskich jako prezesów Ziem Pruskich oraz biskupów chełmińskich, z tym że korespondencja z tymi drugimi często dotyczyła lokalnych sporów o charakterze wyznaniowym (Toruń należał do diecezji chełmińskiej i np. Rada, mając prawo patronatu nad katolickimi kościołami toruńskimi i znajdującymi się w dobrach ziemskich miasta, proponowała ordynariuszowi kandydatów na proboszczów).

Listy wysyłane do pozostałych senatorów Rzeczypospolitej były stosunkowo nieliczne. Często zawierały prośby o interwencje na rzecz miasta na dworze (np. w 1724 r. kiedy to zwrócono się aż do 13 osób), niekiedy też w trybunałach. Znacznie liczniejsze były kontakty korespondencyjne Rady Torunia z okoliczną szlachtą z Prus Królewskich, Kujaw i ziemi dobrzyńskiej. Dotyczyły one zatargów o granice dóbr miejskich, wydzierżawiania tych majątków szlachcie, sporów handlowych (przy spławie), ale też współdziałania w sprawach prowincji. W $1733 \mathrm{r}$. listy adresowane do tej szlachty stanowiły aż $17 \%$ ogólnej liczby oficjalnych pism Rady. Po I rozbiorze i odcięciu od byłych Prus Polskich intensywność tych kontaktów wyraźnie się zmniejszyła. Korespondencja ze szlachtą z dalszych ziem Rzeczypospolitej jest już mniej liczna, często dotyczy sum lokowanych przez te szlachtę w Toruniu i wypłaty odsetek.

Oficerowie wojsk koronnych i litewskich byli adresatami listów Rady Torunia głównie w latach konfliktów wojennych, a więc w dobie wojny północ-

7 Historia Torunia, t. 2, cz. 3: Między barokiem i oświeceniem (1660-1793), red. M. Biskup, Toruń 1996, s. 178. 
nej i później w czasie bezkrólewia 1733 r. oraz działań wojennych stronników Stanisława Leszczyńskiego. Jeszcze wyraźniej ta zależność występuje w wypadku oficerów wojkk obcych i dyplomatów (szwedzkich, rosyjskich, saskich, potem także pruskich). W 1705 r., kiedy to w mieście stał garnizon szwedzki, aż $37 \%$ korespondencji toruńskiej było skierowane do tych dowódców wojskowych z prośbami o zmniejszenie obciążeń. W 1760 r., gdy z kolei w Toruniu kwaterowali Rosjanie, 34\% listów z tego roku wysłano do oficerów, dyplomatów i ministrów rosyjskich. W 1775 r. 14\% korespondencji kierowano do dowódców pruskich. Na uwagę zasługuje natomiast fakt, że Rada Torunia bardzo rzadko zwracała się bezpośrednio do centralnych władz państwa pruskiego w Berlinie.

Niekiedy Rada Torunia czuła się jednak zmuszona odwoływać bezpośrednio do władców państw obcych. W dobie wojny północnej pojedyncze listy wysłano do króla Szwecji Karola XII i cara Rosji Piotra I, w czasach wojny siedmioletniej do carowej Elżbiety, a później, w dobie konfederacji dysydenckiej i rozbiorów, do carowej Katarzyny II. Znacznie więcej pism adresowano do władców państw protestanckich (Wielkiej Brytanii, Danii, Prus i licznych księstewek niemieckich). W 1735 r. wysłano 2 takie listy, w 1740 już 11, a w 1755 r. aż 16 . Zawierały one prośby o poparcie na dworze polskim toruńskich zabiegów o budowę nowej świątyni luterańskiej (na miejsce kościoła NMP zabranego ewangelikom w 1724 r.) i przede wszystkim o datki pieniężne na ten $\mathrm{cel}^{8}$.

Charakterystycznym zjawiskiem jest gwałtowny wzrost korespondencji z lokalnymi (prowincjonalnymi) władzami państwa pruskiego po $1772 \mathrm{r}$. Wcześniej do tych organów władzy wysyłano z Torunia co najwyżej po kilka pism rocznie. Wyjątkiem był rok 1765, kiedy to poszło tam aż 21 listów, ale też dotyczyły one głównie utrudnień w handlu wywołanych przez pruskie cło na Wiśle pod Kwidzynem. Tymczasem w 1775 r. przesłano z Torunia do różnych urzędów zachodniopruskiej kamery kwidzyńskiej i okolicznych pruskich starostów (Hauptmannów) 27 pism, w 1780 r. - 51 listów, a w 1785 r. - 49 (tj. $53 \%$ całej ówczesnej korespondencji Torunia). Liczby te dobrze oddają fakt, że po I rozbiorze miasto ma do czynienia z sąsiadem dysponującym rozbudowaną i dobrze funkcjonującą administracją lokalną, która wciąż domaga się

${ }^{8}$ Szerzej o toruńskich zabiegach za granicą o pieniądze na budowę nowego kościoła luterańskiego zob. C. G. Markull, Der Bau der altstädtischen gelischen Kirche in Thorn, Thorn 1856; S. Wałęga, Dzieje polityczne Torunia u schytku Rzeczypospolitej (1724-1793), t. 1 [do 1756], Toruń 1935, s. 203-281. 
wypełniania powinności (podatki, rekruci, inne zobowiązania rzeczowe) obciążających dobra miejskie Torunia znajdujące się już w państwie pruskim. Administracja ta potrafi też skutecznie egzekwować wyroki swoich sądów (także w sprawach prywatnych). Dla toruńskiego mieszczaństwa był to ewidentny dowód, że ma do czynienia nie ze słabą Rzecząpospolitą (bardzo niewiele listów wysyłano uprzednio do niższych organów polskich władz terytorialnych, których praktycznie, z wyjątkiem administracji celnej, nie było), ale ze scentralizowanym i sprawnie rządzonym państwem absolutnym.

Znaczną część zawartości toruńskich kopiariuszy korespondencji stanowią listy wysyłane przez Radę do miast, z którymi Toruń utrzymywał bliższe stosunki i z których mieszczanami toruńczycy prowadzili handel (wynikały $\mathrm{z}$ tego czasem spory sądowe). Ponadto wielu torunian pochodziło $\mathrm{z}$ innych ośrodków miejskich i nieraz pojawiała się konieczność interwencji Rady w bardziej skomplikowanych sprawach spadkowych. Informowano się też o osobach, które były podejrzane o popełnienie przestępstw, a wywodziły się z innych miast. Najwięcej tego typu listów, zawierających na ogół interwencje w sprawach prywatnych, wysyłano do Gdańska i Elbląga (łącznie po kilkanaście w ciągu roku). W latach dwudziestych XVIII w. korespondencja z Gdańskiem dotyczyła także wzajemnych sporów między kupiectwem i władzami obu miast oskarżającymi się o wprowadzanie zbyt wysokich akcyz na towary będące przedmiotem wzajemnego handlu'. Stałe kontakty listowe utrzymywała Rada Torunia z mniejszymi miastami Prus Królewskich, Grudziądzem, Malborkiem (przeciętnie po 3-6 listów rocznie) i w nieco mniejszym stopniu z Brodnicą (w jej przypadku władze toruńskie wspierały ją w jej sporach ze starostami i biskupami chełmińskimi). Z pozostałymi małymi miastami prowincji pruskiej kontakty Torunia były sporadyczne (Chełmno, Kowalewo, Golub, Świecie, Tczew, Chojnice). Specyficzny był moment pojawienia się częstszych kontaktów z Bydgoszczą. Przez większość XVIII w. Rada Torunia praktycznie nie utrzymywała z tym miastem oficjalnej korespondencji (wyjątkiem 2 listy z 1750 r.). Dopiero po I rozbiorze, gdy Bydgoszcz stała się siedzibą pruskiej regencji i ważnym ośrodkiem handlowym (budowa kanału bydgoskiego) częściej pojawiały się w toruńskich kopiariuszach listy wysyłane do tego miasta.

Z pozostałych miast Rzeczypospolitej uchwytne są sporadyczne kontakty Rady Torunia z Lesznem, Poznaniem, Kaliszem, Wschową, Fordonem, Płoc-

9 J. Dygdała, Konflikty między kupiectwem Gdańska i Torunia z lat 1720-1724, [w:] Strefa battycka wXVI-XVIII w. Polityka - spoteczeństwo - gospodarka, red. J. Trzoska, Gdańsk 1993, s. 197-206. 
kiem, Warszawą, Łowiczem, Piotrkowem Trybunalskim (pochodziło stamtąd kilku zamożnych katolickich kupców toruńskich), Krakowem, Lublinem, Wilnem i kilkoma jeszcze małymi miastami. Dziwi brak listów skierowanych do Lwowa, z którym to miastem torunianie utrzymywali kontakty handlowe, ale wynikać to może z analizy tylko części materiału źródłowego (sondaż objął około $1 / 4$ listów wpisanych do kopiariuszy w latach 1703-1792).

Wyraźnie więcej listów Rady adresowanych było do pobliskich miast znajdujących się w Prusach Brandenburskich (Wschodnich). Na czoło wysuwa się tu Królewiec (początkowo pisma są tam wysyłane sporadycznie, ale w drugiej połowie XVIII w. ich liczba wyraźnie się zwiększa), obok niego występuje Kwidzyn, znacznie już rzadziej Tylża, Działdowo, Bartoszyce, Biskupiec Pomorski, Pasłęk, Prabuty, Olsztynek, Dąbrówno, Kętrzyn i Wystruć.

W miarę częste były kontakty Rady Torunia z Wrocławiem, rzadsze z kilkoma innymi miastami śląskimi: m.in. z Jaworem, Głogowem i Świdnicą ${ }^{10}$. Wśród wychodzącej korespondencji Rady Torunia można odnotować także pojedyncze listy kierowane do miast szeroko pojętej strefy bałtyckiej: Lęborka, Słupska, Szczecina, Stralsundu, a także Kopenhagi i Hamburga. Wśród pozostałych miast Królestwa Pruskiego do których były adresowane stosunkowo nieliczne pisma toruńskiej Rady spotykamy Berlin, Franfurt nad Odrą, Gorzów, Magdeburg i Poczdam. Ponadto warto wspomnieć o kilku listach wysłanych do Görlitz, Drezna, Pragi, Regensburga, a nawet odległych Lindau am Bodensee i Bockenheim w Lotaryngii.

Analizując geograficzny rozkład kontaktów listowych Rady Torunia z poszczególnymi ośrodkami miejskimi, zauważymy dużą zbieżność z miejscowościami, z których pochodziła spora część mieszczan, przybyłych do Torunia w XVIII w. Były to głównie tereny Prus Królewskich i Prus Brandenburskich, Pomorza (Szczecińskiego), Śląska, Brandenburgii oraz tych miast Rzeczypospolitej, w których był stosunkowo duży odsetek ludności ewangelickiej (Wielkopolska) ${ }^{11}$.

Dziwić może stała korespondencja Rady Torunia z uniwersytetem w Lipsku. Wynikała ona jednak z faktu, że Rada była dysponentem stypendiów,

${ }^{10}$ Już od średniowiecza stosunki gospodarcze Torunia z Wrocławiem i Śląskiem były bardzo ożywione, por. K. Kosiński, Gospodarcze i spoteczne kontakty Torunia z Wroctawiem w późnym średniowieczu, Toruń 2005.

${ }^{11}$ Por. szerzej Z. Szultka, Rola i znaczenie spoteczno-ekonomiczne ludności naptywowej Torunia w'świetle ksiag przyjęć do prawa miejskiego, „Zapiski Historyczne” 1972, t. 37, z. 1, s. 56-74. 
ufundowanych niegdyś przez zamożnych toruńczyków, a przeznaczonych na utrzymanie wybranych toruńskich studentów na tym uniwersytecie ${ }^{12}$.

$\mathrm{Z}$ zachowanej w kopiariuszach korespondencji wyłania się obraz stosunkowo częstych kontaktów ewangelickich władz miejskich z najrozmaitszymi katolickimi instytucjami: zakonami męskimi i żeńskimi, kapitułami, kanonikami. Wiązały się one z faktem, że te korporacje duchowne i niektórzy księża złożyli w toruńskiej kamlarii, zarządzającej finansami miasta, znaczne kwoty pieniężne, od których wypłacano im odsetki. Tymczasem w okresach dużych zniszczeń wojennych w początkach XVIII w., lub kłopotów gospodarczych po I rozbiorze, kamlaria nie tylko nie była w stanie regularnie spłacać swych zobowiązań, ale miała także znaczne trudności ze zwrotem sum ulokowanych w mieście ${ }^{13}$.

W niniejszym szkicu zasygnalizowałem już ogólnie tematykę oficjalnych listów wysyłanych przez Radę Torunia. Warto jednak na przykładzie korespondencji z jednego tylko, sondażowo wybranego roku 1740, bliżej przedstawić problematykę zawartą w wysłanych wówczas 134 listach Rady ${ }^{14}$. Ewidentnie dominowała sprawa zabiegów o uzyskanie zgody króla Augusta III i władz Rzeczypospolitej na budowę nowego kościoła protestanckiego w Toruniu, a także próśb skierowanych do współwyznawców o wsparcie finansowe tej inwestycji. Tematyki tej dotyczyło aż 35 listów (26\%). Rada Torunia zwracała się m.in. z prośbami do pierwszego ministra Henryka Brühla, kanclerza wielkiego koronnego Andrzeja Stanisława Załuskiego i podskarbiego wielkiego koronnego Jana Ansgarego Czapskiego o umożliwienie toruńskiemu rajcy Chrystianowi Klosmannowi odbycie audiencji u króla Augusta III.

Drugie miejsce zajmowały w tej korespondencji (15 pism) spory z okoliczną szlachtą (m.in. o zbiegłych poddanych, o Cyganów, którym niektórzy ze szlachty udzielali gościny, o komisję królewską, która rozpatrywała długotrwały zatarg miasta ze starostwem soleckim o kępę na W iśle, o kamienicę Kruszyńskich w Toruniu). W 11 listach skierowanych do najwyższych urzędników i senatorów (kanclerza koronnego Andrzeja Stanisława Załuskiego - 5 pism,

${ }_{12}$ M. Pawlak, Studia uniwersyteckie mtodzieży z Prus Królewskich w XVI-XVIII w., Toruń 1988, s. 96-99; Z. H. Nowak, Studia lipskie Samuela Bogumita Lindego i jego starania o lektorat jezyka polskiego na uniwersytecie lipskim 1789-1792, „Zapiski Historyczne” 1969, t. 34, z. 4, s. 38-41 .

13 Historia Torunia, t. 2, cz. 3., s. 174, 245, 284.

14 Archiwum Państwowe w Toruniu, Akta miasta Torunia, Katalog II, dział I, t. 41, s. 293 $-498$. 
marszałka wielkiego koronnego Franciszka Bielińskiego - 1, wojewody chełmińskiego Michała Bielińskiego - 2 i wojewody malborskiego Piotra Jerzego Przebendowskiego - 3) Rada prosiła ich o interwencje w różnych sprawach sądowych, w które uwikłane było miasto, bądź jego mieszkańcy. M.in. 2 listy dotyczyły sporu ze znanym pieniaczem Łukaszem Konopką, który pozwał Toruń o zwrot sumy pożyczonej przez jednego z mieszczan toruńskich (zmarłego zresztą bezpotomnie) jeszcze w drugiej połowie XVII w. Sprawa ta, zakończona sukcesem miasta, ciągnęła się przez kilkadziesiąt lat, przed wszystkimi możliwymi instancjami sądowymi, angażując w nią także dwór królewski i kanclerzy ${ }^{15}$. Można byłoby do tej grupy zaliczyć jeszcze 4 listy z instancjami za Elblągiem w sprawie toczącej się przed sądem asesorskim. 10 listów zawierało najrozmaitsze wyjaśnienia związane z pozywaniem mieszczan toruńskich i samego miasta przed sądy.

Spora część korespondencji poruszała sprawy gospodarcze. M.in.: 9 pism dotyczyło jarmarków, spraw cechowych i testamentów; 8 listów utrzymania w odpowiednim stanie toruńskiego mostu przez Wisłę (zwracano się do sejmików wielkopolskich o pomoc finansową w remoncie mostu); 5 listów dotyczyło prowizji (odsetek), kapitałów złożonych w mieście i obligacji. Sprawa długów zaciągniętych w Toruniu, a obciążających kościół katolicki w Ostromecku była tematem 4 listów. W 2 listach wysłanych do Krakowa Rada Torunia upominała się o dotrzymanie warunków kontraktu, jaki tamtejsi mieszczanie Toriani i Klug zawarli na dostawę 26 łasztów wapna. Pojedyncze listy dotyczyły organizacji poczty toruńskiej i pogłównego (spierano się jaką monetą ma być ono opłacane).

Sprawy związane z przygotowywaniem obrad przedsejmowego sejmiku generalnego Prus Królewskich występują w 5 listach, a 2 listy dotyczą przyznania stypendiów na studia na uniwersytecie lipskim dla dwóch młodych torunian.

Pełna analiza całej zachowanej oficjalnej korespondencji Rady Torunia mogłaby oczywiście przynieść jeszcze nieco nowych, szczegółowych informacji (zapewne okazałoby się, że Toruń utrzymywał też kontakty z niektórymi miastami szwedzkimi, inflanckimi, czy węgierskimi - w tym słowackimi). Wydaje się jednak, że w ogólnym obrazie aktywności toruńskiej kancelarii miejskiej i geograficznego zasięgu jej korespondencji nie nastąpiłyby zasadnicze zmiany.

15 Zob. S. Wałęga, Z dziejów praktyki sądowej XVII i XVIII wieku. U źródet zatargu miasta Torunia ze szlachcicem Eukaszem Konopka, „Zapiski Historyczne” 1969, t. 34, z. 1, s. 79-101; z. 2, s. 35-58. 


\section{ANEKS}

Liczba listów wysłanych przez Radę Torunia i ich adresaci

\begin{tabular}{|c|c|c|c|c|c|c|c|c|c|c|c|}
\hline Rok & 1705 & 1710 & 1715 & 1720 & 1724 & 1725 & 1730 & 1733 & 1735 & 1740 & 1745 \\
\hline Liczba listów & 106 & 185 & 155 & 132 & 171 & 115 & 162 & 145 & 94 & 134 & 89 \\
\hline Liczba stron & 82 & 292 & 235 & 91 & 191 & 145 & 190 & 212 & 160 & 205 & 74 \\
\hline Królowie polscy & 1 & 7 & 2 & 4 & 11 & 3 & 2 & 6 & 1 & - & - \\
\hline Władcy obcy & 1 & - & - & - & - & - & - & - & 2 & 11 & - \\
\hline Biskupi chełmińscy & 1 & 9 & 1 & 4 & 9 & 2 & 6 & 6 & - & 1 & 2 \\
\hline Biskupi warmińscy & - & 1 & 2 & - & 1 & - & 2 & 2 & - & 1 & 2 \\
\hline Prymasi & 1 & - & - & 1 & 1 & 2 & 2 & 6 & 1 & - & - \\
\hline Kanclerze & - & 11 & 4 & 8 & 16 & 8 & 15 & 2 & 2 & 7 & 16 \\
\hline Marszałkowie & - & - & 6 & 3 & 1 & 1 & - & 2 & 1 & 1 & 1 \\
\hline Podskarbiowie & - & 1 & - & - & 2 & 1 & - & 2 & - & 2 & 5 \\
\hline Hetmani & - & 2 & 1 & - & 7 & 1 & - & - & - & - & - \\
\hline $\begin{array}{l}\text { Senatorowie Prus } \\
\text { Król. }\end{array}$ & 4 & 7 & 9 & 14 & 5 & 6 & 11 & 13 & - & 9 & 2 \\
\hline Senatorowie & 1 & 1 & 2 & 1 & 13 & 5 & 1 & 9 & 1 & 2 & 13 \\
\hline $\begin{array}{l}\text { Urzędnicy kor. i sa- } \\
\text { scy }\end{array}$ & - & 2 & 5 & 2 & 3 & 2 & 4 & - & 1 & 2 & 7 \\
\hline $\begin{array}{l}\text { Szlachta z Prus } \\
\text { Król., Kujaw i ziemi } \\
\text { dobrzyńskiej }\end{array}$ & 10 & 12 & 13 & 7 & 16 & 21 & 23 & 25 & 8 & 16 & 12 \\
\hline Szlachta pol.-lit. & - & 13 & 5 & 6 & 3 & 2 & 4 & 1 & - & - & - \\
\hline Oficerowie pol.-lit. & 4 & 4 & 7 & 1 & 3 & 3 & 6 & 14 & 7 & 1 & 2 \\
\hline $\begin{array}{l}\text { Oficerowie } \\
\text { i ministrowie } \\
\text { obcych państw }\end{array}$ & 39 & 15 & 2 & - & - & 2 & 1 & - & 6 & 8 & 4 \\
\hline $\begin{array}{l}\text { Urzędnicy lokalni } \\
\text { Prus Brandenbur- } \\
\text { skich }\end{array}$ & - & 2 & 2 & 1 & - & - & - & - & - & 5 & - \\
\hline $\begin{array}{l}\text { Deputowani i rezy- } \\
\text { denci Torunia }\end{array}$ & 10 & 57 & 53 & 20 & 32 & 23 & 7 & 15 & 27 & 6 & - \\
\hline Gdańsk i Elbląg & 5 & 16 & 1 & 6 & 10 & 7 & 18 & 17 & 2 & 3 & 3 \\
\hline Gdańsk & 3 & 7 & 11 & 10 & 16 & 4 & 15 & 4 & 3 & 6 & 5 \\
\hline
\end{tabular}


Rok

$17501755 \quad 1760 \quad 176$

Szlachta z Prus Król.,

Kujaw i ziemi

dobrzyńskiej

Szlachta pol.-lit.

Oficerowie pol.-lit.

Oficerowie i ministrowie obcych państw

Urzędnicy lokalni Prus

Brandenburskich

Deputowani i rezydenci

Torunia

Gdańsk i Elbląg

Gdańsk

Elbląg

Brodnica

Chełmno

Grudziądz

Malbork

Bydgoszcz

Poznań

Warszawa

Berlin

Królewiec

Kwidzyn

Wrocław

Uniwersytet lipski

3

- $\quad-\quad 2$

- $\quad-\quad 1$ $\begin{array}{llllllllll}13 & 13 & 3 & 11 & 3 & 1 & 2 & 7 & 5 & 3\end{array}$

$\begin{array}{rlllllllll}- & 2 & 1 & 2 & 2 & 1 & 2 & 5 & 1\end{array}$

$\begin{array}{llllllllll}- & 1 & 46 & 6 & 5 & 17 & 17 & 5 & 5 & 16\end{array}$

$\begin{array}{llllllllll}3 & - & 1 & 21 & 7 & 19 & 27 & 51 & 49 & 32\end{array}$

$9 \quad-\quad-\begin{array}{llllllllll} & & 16 & 13 & 1 & 6 & - & -\end{array}$

$\begin{array}{llllll}5 & 1 & 3 & 35 & 47 & 13\end{array}$

$\begin{array}{llllllllll}4 & 6 & 9 & 6 & 14 & 18 & 15 & 7 & 1 & 5\end{array}$

$\begin{array}{llllllllll}11 & 3 & 3 & 2 & 10 & 15 & - & 1 & 3 & 2\end{array}$

$\begin{array}{llllllllll}4 & - & 1 & 6 & 6 & 4 & 1 & 1 & - & 1\end{array}$

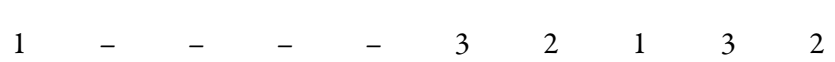

$\begin{array}{llllllllll}3 & 1 & 3 & - & 9 & 7 & 3 & 1 & - & 2\end{array}$

$\begin{array}{lllllllllll}3 & 1 & 1 & 2 & 2 & 2 & - & 1 & 1\end{array}$

2 - $\quad$ - $\quad-\quad-626$ -

$\begin{array}{lllllllllllll}-1 & 1 & 5 & 1 & 1 & - & - & - & -\end{array}$

$\begin{array}{lllllllll}- & - & 2 & 15 & 9 & 5 & 1 & 2 & -\end{array}$

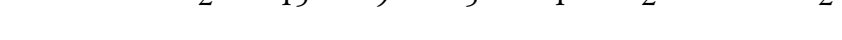

Podstawa źródłowa: Archiwum Państwowe w Toruniu, Akta miasta Torunia, Katalog II, I 36-53: Księgi listów Rady Torunia (Briefbücher, Missiva) 1793-1792 . 


\section{Letters sent from Torun City Council in 18th Century: addressees, frequency, extent (Summary)}

The article presents an analysis of a correspondence exchanged by the city council of Thorn in the $18^{\text {th }}$ century. The analysis was based on books of correspondence (Missiva, Briefbücher), in which copies of official letters sent from the city were registered. The author noticed, that the number of exchanged letters rose during important political events (the Northern War, the Tumult of Thorn, general diet followed by great diets).

The author established a list of the most important addressees of the official letters sent from the city. City Council sent lots of letters to residential-secretary, to whom realization of city policy at the court was entrusted, as well as directly to central authorities of Polish Commonwealth, senators from the Royal Prussia, and other cities, which were economic partners of Thorn (mainly from the Royal Prussia and Brandenburg-Prussia, Pomerania - a part with city of Stettin, Silesia, Brandenburg, and other cities from the Commonwealth, in which inhabited significant percentage of Protestants, i.e. in Great Poland).

On an example of the correspondence sent in 1740, the author enumerated a list of subjects taken up in official letters of City Council of Thorn, among which were: trials, economic affairs, issues related to organization of a general diet of the Royal Prussia. There is an supplement added to the article in which the author in a vast table presented information about number of letters sent by the City Council of Torun in every particular year from analyzed above.

trans. Wiesława Duży

Jerzy Dygdała

Instytut Historii Polskiej Akademii Nauk im. Tadeusza Manteuffla, Pracownia Historii Pomorza i Krajów Bałtyckich, Toruń 